\title{
Sacred Geography of the Post-Socialist Balkans: Transformations of Religious Landscape and Pilgrimage An Introduction
}

\section{Evgenia Troeva}

Institute of Ethnology and Folklore Studies with Ethnographic Museum, Bulgarian Academy of Sciences, Sofia, Bulgaria troeva@abv.bg

\section{Petko Hristov}

Institute of Ethnology and Folklore Studies with Ethnographic Museum, Bulgarian Academy of Sciences, Sofia, Bulgaria

hristov_p@yahoo.com

This introductory text aims at presenting the dynamics in the development of religious life in the post-socialist Balkans and the trends in its research from the perspective of the humanities and social sciences. The topic has geographical as well as political and temporal limitations. The transformations in the political, economic, social and cultural development of the former socialist countries have been taking place hand in hand with significant changes in religious life as well. The officially imposed atheistic ideology and the restriction on religious practice during socialism have been followed by a manifestation of religious feelings, particularly in the 1990s. The different faiths traditional for the region have come alive in the public sphere. After 1989, the religious sphere became more pluralized in the countries of the Eastern bloc, and new religious movements such as neo-Protestantism, Eastern teachings, New Age ideas, etc. began to spread.

The intensification of religious practice in post-socialist countries raises the question of defining the processes observed. The research corpus on the issue can be grouped into four major theses: on the revitalization of religion; on the important differences in the religiousness of different countries; on religion as an important identity framework for social processes; and on the role of religion in the new pluralistic social environment (Jerolomov, Zrinščak 2006: 280). Researchers of religion in Eastern Europe define the observed processes 
as 'religious resurrection' (Tomka 2011), 'revitalization' of current religious practice (Blagojević 2009: 69) or 'a return' of religiosity (Karamihova 2007a); unfortunately, most anthropologists and sociologists failed to observe 'the particular shape and form of this religious growth and the structural changes of the religious representations triggered by the post-socialist period' (Gog 2006: 51). The increased importance of religion can be attributed to its function of reconstructing the political and geopolitical identity in the post-socialist era (Borowik 2006: 272). Researchers point out that the general crisis of the communist model of modernization has led to a moral crisis, which in turn has resulted in turning to religion (Iveković 2002: 523); according to a thesis of the Croatian sociologist of religion Vrcan the 'crisis of religion' has turned into a 'religion of crisis' (Vrcan 1986). This turning to religion in Eastern Europe is motivated by the quest for cultural identity, social regeneration and fulfilment of spiritual needs (Tomka 2002: 537). However, referring to Sorin Gog we can also note that 'the church loses her privileged position of hosting the religious experience and the process of de-institutionalization of religious experience leads to structural changes on the locus of the church in society' (Gog 2006: 42). Instead of being an indicator of pure faith, in the 199os religious belonging in the Balkans changes into an act of confirmation of cultural and ethnic affiliation more and more frequently, especially in critical situations such as the wars in former Yugoslavia (see for example: Ognjenović, Jozelić 2014).

The post-socialist 'religious resurrection' is looked upon as an aspect of the global rise of religiousness (Benovska-Sŭbkova 2012: 49) as well as a process of construction of new identities. In this respect this volume is part of a more general debate on secularization in Europe and around the world. After the triumph of the secularization theory in the social sciences during the second half of the 20 century, the end of the century ushered in doubts regarding its cogency with respect to the observed phenomena and raised the question as to whether secularization is a modern myth (Pollack 2003). Researchers state correctly that modernization does not necessarily lead to secularization, and in this respect secularized Europe is more of an exception ${ }^{1}$ rather than the norm (Berger, Davie, Fokas 2008). Modernization causes secularization as well as counter-secularization movements, while even in Europe we could speak of a change in the institutional role of religion rather than of secularization (Berger 2004: 11, 22). While the supporters of secularization use the processes in the Christian churches in Europe as their empirical base, the critics of secularization theories base their justification on examples of religious practices

1 Davie allowed a concession: believing without belonging, but only in the case of Europe, which stands as an exception there - her influential book of a few years before is entitled along the same line: Europe: The Exceptional Case (Davie 2002). 
from different geographical regions and different faiths (Zielińska 2013: 34). The 'modern' privatized social form of religion is characterized by a de-monopolization of the production and distribution of world-views (Luckmann 2003: 281). According to J. Casanova we are witnessing a 'deprivatization' of religion (Casanova 1994). The observations on religious life in the post-socialist Balkans fit in with this theoretical debate. The extent to which the conclusive analysis based on the research and juxtaposition of religiousness in Western Europe and the USA is confirmed by the processes in the Balkans is one of the questions this paper seeks to answer.

It is part of the debate about the extent to which the religious processes in the contemporary Balkans are in harmony with the religious practices in posttotalitarian Central and Eastern Europe. There are already some studies on the relations between religion and politics in the post-socialist space in Central Asia and East-Central Europe (Hann et al.: 2006) as well as in a number of post-socialist countries of Central and Southeastern Europe (cf. Stan, Turcescu 2007; Ramet 2014). In her study 'The Religious Landscape of Central and Eastern Europe after Communism' I. Borowik formulated five reasons why Central and Eastern Europe should be differentiated from the rest of Europe in terms of religion. The first is that Christianity reached most of these countries later than it did in the West; the second is that in most Eastern European countries Eastern Orthodox Christianity prevailed, while in most Central European countries, it was Roman Catholicism which dominated; thirdly, in the East, religions became consolidated during the same process in which national identity and tradition were constructed, which was not the case in the West. The fourth reason for the unification of Central and Eastern Europe lies in the historical and political experience of religions, which had to struggle with communism and anti-religious totalitarian regimes; the fifth reason is found in the collapse of communism (Borowik 2007: 654-669). However, as Dragoljub Đorđević justifiably noted, the situation in Tito's Yugoslavia was quite different from other Central and Eastern European countries, and it is unclear why Borowik failed to mention this difference - 'more precisely, the first three reasons that she brought out apply to Yugoslavia, but the fourth and the fifth one do not matter at all' (Đorđević 2008: 7).

Apart from the differences from a historical perspective, the problem has its methodological dimensions too, expressed in the acceptance or adaptation of research methodologies and clarifying theoretical paradigms spread in the western world by Eastern European ethnologists and anthropologists in the years after 1989. The researchers of religion in Eastern Europe are increasingly turning to anthropological methods (Benovska-Sŭbkova 2012: 52). At the same time in the post-socialist Balkan countries there are terminological differences. Serbian ethnology continues to use the term 'folk religion', which established 
itself during socialism. According to Ivica Todorović the term (Serbian) 'folk religion' stands for a complex phenomenon encompassing the practice and perception of Orthodox Christianity by the wide masses of people living in the villages, as well as the overall Serbian religious context (the theological and religious legacy of the Serbian Orthodox Church), along with alternative models which might include unorthodox influences coming from other traditions and cultures (Todorović 2008: 67). Bandić claims that 'Serbian peasants have accepted Christianity but they have often perceived it in an unchristian way' (Bandić 2004: 12). Thus 'folk religion' is defined as 'Orthodox Christianity as interpreted by the people or the widest strata of society' (Bandić 1997: 257). In Croatia the term 'pučka religioznost' describes both the extra institutional religious practices and the neocatechumenal movement for the renewal of the Roman Catholic Church. Contemporary Bulgarian ethnology offers examples of using terms like 'folk' or 'people's' religion (Georgieva 2012) to define the different forms of practising Christianity and Islam, as well as a preference for the terms 'religiousness' and 'local religion', implying religion in its institutional modes and organization along with the diverse reflections of religiousness in everyday life (Vŭlchinova 1999: 15-16), a vision we share.

The Balkans have a specific confessional configuration. For centuries the peninsula has been a meeting point of Orthodox Christianity, Catholicism, Islam and Protestantism. Their followers make up different proportions in the individual Balkan countries. The structuring of the modern nations in the Balkans during the 19th century was based on confrontation of the religious 'other', while the close linking of religion with ethnic identity continued into the 2oth century. ${ }^{2}$ The second half of the century entered Balkan history with the attempt to create nations of a new socialist type, whose ideological platform was communism rather than a religion traditional in the region. The different countries, however, followed a different historical development both in the socialist era and after its collapse. The collapse of the communist project and the breakup of Yugoslavia as a result of the military conflicts in the Balkan states during the 199os have played a significant role in the various forms and practices of the religious (Radeljić, Topić 2015). In the transition years religion in the former Yugoslavia became a source of political (and national) legitimacy (Cvitković 2012; Detrez 2015). The church institutions do not hide their sympathies for some of the warring parties (Iveković 2002: 525; Buchenau 2006; Jakelić 2010; Henkel 2011). Ivan Čolović refers to post-Milošević Serbian nationalism as a civic religion, or rather as a 'political religion' (2011: 168). According to his interpretation the new national ideology in Serbia, based also

2 Albania is an exception to this tendency. 
on folk Orthodoxy, constructs a particular mythical space as a network of symbolical places: cloisters, towers, battlefields, sacred rivers, mountains, and forests, but the most essential places in this mythical topology, however, are graves, especially of Serbian heroes. The re-traditionalization (in the Serbian Orthodox-national style) is referred to 'as an answer to the social crisis and crisis of values' in Serbian society (Ramet 2014: 12). Zrinčšak talks about 'new believers' in post-communist ex-Yugoslav states and revitalization of religion, the greater religiosity being provoked by social processes (Zrinčšak 2006: 77-78).

A close link between the Orthodox Church and political parties ${ }^{3}$ is evident in Romania, too (Maner 2012: 92). A politicization of religion but in the form of ethnicity is also recognizable from post-1997 Montenegro (Dzankic 2016: 123). A. Krasteva uses the term 'elastic (post)secularism' in order to conceptualize the eclectic forms of the post-communist politicization of the religious and the religionization of politics in Bulgaria (Krasteva 2015). Nowadays religion in the Balkans offers an integrating framework for post-socialist societies which have a problem defining their new identities; religious beliefs are associated with the new ethno-national projects, providing a sense of continuity with their pre-communist past (Iveković 2002: 534). The observations of Gabor Barna on post-socialist Hungary are applicable to the Balkans in this respect: 'In the second half of the 2oth century, a new generation of believers reached back to an older religious practice, thus embracing a tradition of earlier generations and adapting it to new social and church circumstances; tradition has been given a new function and a new social role' (Barna 2012: 65).

Identity conflicts on the border zones of the Balkans have intensified the symbolic importance of the religious. For example, the desecularization typical of Bosnia during the socialist period was replaced under the influence of the war in the 1990s by a greater interest among the Muslim population in Islam and represented in the return of the wearing of headscarves by women (Iveković 2002: 531). During the war in Bosnia and Herzegovina from 1991 to 1995 it was not just ancient bridges that were destroyed but a number of churches and mosques too. Later they were rebuilt as markers of their own territory, which has turned them from 'holy places' into 'stony borderlines' (Cvitković 2012: 20-21). The frequently repeated slogan in times of ethnic war over territory, which says that Serbia is everywhere where Serbian graves are located, represents a renewal of ideas about ethnic space and the sovereignty of the ethnic group in its territory (Čolović 2000). During the military conflict in Kosovo the houses of worship of the two warring parties were demolished

3 On Serbia, Montenegro, Macedonia and Bulgaria, see Nonka Bogomilova's study (Bogomilova 2005). 
(Kolczyńska 2012: 171). The border contact zones in the Balkans turned from zones of coexistence into zones of conflict and demonstrative practice of religious identity during the 1990s. They have become a peculiar research field where ethnologists and sociologists of religion are discovering new challenges.

During the transition years researchers started paying more attention to the minority religious communities in the Balkans. The ethno-religious communities whose religious practice was suppressed under socialism after 1989 began to demonstrate their group identity by showing increased interest in their religion. Such tendencies can be traced among Bulgarian Catholics (Bokova 1999: 57-82), Bulgarian Evangelical Christians (Altanov 2012: 90-105) and Bulgarian Muslims (Troeva 2011). These communities manifest their faith by participating in religious rituals. During the transition years Bulgarian Catholics resumed organizing processions, celebrating church holidays and the practice of erecting huge crosses next to or in the vicinity of the church (Bokova 2000: 10). The Churches of God and their branches and formations in Bulgaria (such as the Bulgarian Church of God, United Churches of God, God's Church in Bulgaria and the New Charismatic communities) laid the foundations of Protestant theological education in Bulgaria, and today they are actively involved in all social processes in the country (Altanov 2012: 104-105).

Some changes in religious life in a number of Muslim communities in the Balkans occurred: the traditionally practised Islam was replaced by other forms closer to the canon and influenced by Salafism (Ghodsee 2009; Merdjanova 2013; Endresen 2015; Elbasani, Roy 2015; Troeva 2016). A study on the Balkans carried out by the British Academy also identifies Salafist influences in a number of Balkan countries. ${ }^{4}$ This is particularly characteristic of communities building their collective identity on the basis of religion (Troeva 2011).

Similar processes could be observed in the rest of the Balkan post-socialist countries as well. In Albania the closing down or demolition of religious centres between 1967 and 1990 led to a manifestation of the local religion once the restrictions were lifted (De Rapper 2010). At the same time in both Albania and Kosovo the ruling parties adhere to a secular model of government (Kolczyńska 2012: 178). The revitalization of religion in Bosnia and Herzegovina manifests itself as desecularization of public life (Abazović 2007: 52). In the new Balkan country what becomes evident is a re-Islamization of national, political and cultural identity (Abazović 2007: 53). The building of houses of worship (mosques, meschits) is thriving among Muslims in Macedonia, Bulgaria and Bosnia. Similar processes give grounds for researchers to talk about a return of the religious, and more particularly of its role as a topical language

4 http://www.balkanmuslims.com/papers.php, accessed on 2 October 2013. 
of expressing a cultural and community belonging; they specify at the same time that it is not religion returning to the social environment but ethnoconfessional communities (Elchinova 1999: 8). 'The return' of the religious indicates the process of the social reconstruction of the local community into the register of the religious practice (Bokova 1999: 63), a process clearly tangible in the conditions of pan-European mobility - the Gastartbeiters returning to their home towns in the former Yugoslav republics give special care to their local religious sites, churches and votive places (for examples in Serbia and Macedonia, see Hristov 2012).

The topic of the religious vacuum during socialism is also subject to criticism, which imposes a new approach to definitions with more shades of meaning like the process of religious resurrection after 1989 (Valtchinova 2001; Valchinova 2012: 73). Researchers in the Balkans claim that the return of religion has occurred (into the public sphere) and not the return to religion 'as there has been no 'departure' after all' (Cvitković 2009). 'The return' of the religious is put in inverted commas as in fact the religious has changed its forms of presence and functioning in the modern society (Bokova 1999: 58). If we use Miklosh Tomka's metaphor, the post-socialist resurrection of religion has 'a resurrected body' which 'however is not identical with the old one' (Tomka 2001: 8). It has been pointed out that 'the return of religion' is one of the formulas to describe the process of democratization in the post-socialist era (Bokova 1999: 75; Elchinova 1999: 7).

One of the most evident reflections of the religious 'revival' in the postsocialist Balkans is the building of houses of worship; in this case of religious manifestation the upsurge of religious activity of lay people is directed towards creating material objects of faith rather than gaining religious knowledge (Valchinova 2007: 38; Valchinova 2012: 73; Hristov 2012). A real boom in the construction of religious buildings is to be found in Romania, for example, where around 200 churches are being built annually (Maner 2012: 88). Researchers claim that the main driver of the post-socialist Orthodox revival was not the Church, but rather lay people (Valtchinova 2007: 7). The Orthodox revival in post-socialist Bulgaria 'owes much to traditional 'religious' or quasi-religious authorities, as well as to developments that occurred in the field that socialism labeled "spirituality" (Valtchinova 2007: 24).

It is worth pointing out that Christianity is being practised as a depersonalized tradition (Kanev 2002: 87). The observations of Grace Davie on Western Europe where lots of people believe without belonging to a religious institution (Davie 2000) differs from the observations on religiousness in Serbia, for example, where people belong to a church institution without believing (Djordjević 2009: 58). At the beginning of the new millennium in Croatia 
they talk about 'the complexity of the religious situation, but first of all the influence of social circumstances and the new social role of religion over the religious profile which is, among other things, reflected in the stabilization of the religious situation and overcoming the pattern which may be described as 'believing in belonging". The researchers' attention is directed towards the study of amateur religious movements, religious experience and the question of identity (Zrinščak 2008: 31-36).

Undoubtedly, the institutional discords and schism in the Orthodox churches in Bulgaria, Macedonia and Montenegro (Dzankic 2016) are reflected in the religious practice and the identification with religious institutions. In Bulgaria church attendance is sporadic and identifying with Orthodox Christianity is primarily of cultural and legitimizing significance (Bogomilova 1998: 356-357). It is along these lines that we should read sociological polls according to which around $15 \%$ of the respondents declare that they are 'deeply religious'. ${ }^{5} \mathrm{Re}-$ searchers noted a much more prominent position of the Serbian and Romanian Orthodox Churches and a stronger nationalism compared to the Bulgarian Orthodox Church due to their different historical development (Flora, Szilagyi, Roudometof 2005; Dungaciu 2006; Voicu, Constantin 2012; Buchenau 2012: 83). Unlike Bulgarian monasteries, in Romania monasteries are full of monks and nuns, many of whom are young people (Pătru 2011: 69). Pickel made the suggestion that this is due to the fact that some countries such as Romania have not reached the threshold of 'religious normalization', at which point they will follow the process of secularization (2009: 9).

The medicalization of religion we witness today (Vŭlchinova 2012) results in an upsurge of pilgrimages and a thriving of a number of sacred places in the Balkans. Researchers have been pointing out that people go on pilgrimages much more often during transition periods and crises caused by economic and social instability and during times of searching for identity (Dorondel 2002). In regions of mixed ethnicity and religions it can be looked upon as an identity laboratory of its own kind, where the dimensions of ethno-religious conflict and symbiosis are at work (Duijzings 2000: 3). This has been the reason for a number of pilgrimage centres to be thriving in the complex context of the post-socialist Balkans. The phenomenon has not gone unnoticed by researchers, who have analysed different aspects of the motivation, the forms and practice of pilgrimage in the different countries. Various pilgrimage centres and practices are being researched in Bulgaria (Valtchinova 1999, Valtchinova 2005, Valtchinova 2008; Troeva 2011; Georgieva 2012; Baeva 2012;

5 Sociological polls claim a higher percentage of religiousness among Muslims compared to Christians (Bogomilova 1998: 355-357). 
Baeva 2012a), in Macedonia (Malinov 2007; Hristov, Hristova 2014: 45-61), in Bosnia-Herzegovina (Markle, McCrea 1994), in Serbia (RadisavljevićĆiparizović 2011; Jovanović, Petrović 2012; Ćiparizović 2015), in Romania (Dorondel 2002; Şerban 2010; Grigore 2015; Beloiu 2015), and in Montenegro (Bakrać 2012: 134; Božovic 2010). Cult sites visited by people of various faiths in Macedonia, Albania, Bosnia and Herzegovina, Bulgaria and Serbia have attracted particular attention (De Rapper 2010; Troeva 2011; Albera, Couroucli 2012; Radisavljević-Ćiparizović 2010). However, research focused on pilgrimages in a comparative Balkan perspective is quite rare: such examples are the studies of pilgrimage compounds Krŭstova Gora in Bulgaria and Medjugorje in Bosnia and Herzegovina (Valtchinova 2009), as well as a collection of comparative studies on pilgrimage in the Balkan countries (Radisavljević-Ćiparizović, Todorović 2011). The pilgrimage topic is analysed from different approaches: typology of cult places on the Balkans is offered (Krstic 2010); gender aspects of pilgrimage are examined (Radulovic 2010); and the relationship between local religion and identity is explored (Valchinova 1999). One of the tendencies observed in the context of pan-European mobility is the increased interest in local places of worship and monuments, such as Christian chapels, Muslim tekkes and village mosques renovated by Gastarbeiters who had returned from Western Europe (Hristov 2012: 287-294). In this way the places where the local community practise their religion are turned, on the one hand, into milestones of local identity and memory in the globalizing world, and on the other into a major part of the local cultural and religious landscape.

Researchers of religiousness in the Balkans analyse a wide range of topics such as the formation and functions of the image of Balkan fortune tellers and prophets in the past and at the present time (Valchinova 2006), the functions of informal religious organizations (Baeva, Valtchinova 2009), the cult towards saints - protectors of settlements (Popov 2012), the question of attire as a religious symbol (Kiurkchieva and Koseva 2012), and instrumentalization of signs of religious affiliation (Troeva 2015). The proliferation of New Age ideas (Potrata 2004; Troeva 2016a) and New Religious Movements (Črnič, Komel, Smrke, Šabec, Vovk 2013; Toncheva 2015) in the post-socialist years has also aroused interest. Researchers emphasize some new processes of conversion from Islam to Christianity or Protestantism among different ethnic groups (Branković, Đorđević 2006, Karamihova 2007, Troeva 2011). In search of new identity particularly intensive processes of conversion to Evangelical denominations have been observed in recent years among various Orthodox as well as Muslim Roma groups (for Bulgaria cf. Slavkova 2007, Benovska-Sabkova, Altanov 2009: 133-156; for Romania cf. Fosztó 2007; for ex-Yugoslavia cf. Todorovic 2004). 
The analysed fields of research on post-socialist religiousness on the Balkans do not cover the diversity of studies on the topic. This thematic volume focuses on sacred geography and pilgrimage. We came up with this topic after long years of doing research in Bulgaria, Macedonia, Moldova, Serbia, Romania and Croatia among various ethnic and confessional communities, among Christians (Orthodox, Catholic and Protestant) and Muslims. The diversity of contexts, forms and practices the ethnographic terrain offers sets challenges for researchers in their attempts to gain an insight into the religious landscape of the Balkans in the post-socialist decades. For centuries the Balkans have represented a contact area of different world religions and their various denominations. On the one hand, here is one of the historical centres of Christian civilization and on the other hand, since the 14th century Islam has been an integral part of the culture of many different ethno-confessional groups on the peninsula. Our goal was to present studies on various sacred places which are related to Christianity and Islam, as well as on the ritual practices performed in these places.

The sacred centres in the Balkans function in numerous dimensions nowadays and defy being fitted into any confessional, ethnic and institutional frameworks. A case study carried out by Biljana Sikimić at a pilgrimage site popular among Serbian Orthodox Christians in Kosovo, a site venerating the cult around the Virgin Mary, situated in the village of Letnica where formerly there used to be a Catholic cathedral, comes to prove again the mingling of religious practices in a number of sacred places in post-war former Yugoslavia. The study confirms the functioning of such local cults dedicated to a sacred statue of the so-called Black Madonna, as an invariable part of religious life even in isolated enclaves. Evgenia Troeva's study presents the geography of major sacred places in contemporary Bulgaria, the emergence of new centres of worship, as well as temporary ones due to the visits of cult objects in a particular location. The focus of the study is on Orthodox sacred places although Muslim, Catholic and Jewish pilgrimage centres are described as well. Without claiming to cover the question from a geographical, methodological and interpretative perspective, we hope that the works of specialists from Bulgaria and Serbia in the current issue dedicated to sacred geography will contribute to providing an insight into post-socialist religiousness in the Balkans, into the developing trends and the changing social context in this part of Europe.

\section{Conclusion}

Based on the thesis that the meaning of religion is socially construed (Beckford 2003: 197), it is worth pointing out that the new changing contexts in the 
post-socialist Balkan countries alter the forms, the role and the rationalization of religious practice nowadays. On the one hand, religion on the Balkans continues to be one of the means to express identity and a sense of belonging to a certain community. Religious places often function as reference points of local identity, as 'memory places', through which the communities express their sense of ownership of a given territory. This is a characteristic feature of border areas and areas of mixed population, where religious symbolism is markedly visible. At the same time the religious processes in the Balkans share common characteristics with the phenomena in the rest of Europe and around the world. Secularization, individual perception of the religious, pluralization of religious ideas as a result of the new media environment, globalization and migration are common in the Balkans too. Eastern and New Age ideas and new religious movements continue to spread, which gives grounds to a puzzle of ideas, forms and practices in the religious field.

Christian denominations returned to the public sphere and remain or become closely linked to political projects in the different countries. The Hanafi Islam practised in the Balkans is in some respect changing under the influence of Salafism while re-Islamization occurred among many Muslim communities as a form of establishing a new identity. There are also the processes of conversion from Islam to Evangelicalism or Orthodox Christianity among the Roma communities, Albanians and Muslim Bulgarians. The presence of religious minorities in each Balkan post-socialist country leads to different policies and legal frameworks for practising religion. In this respect the accession to the European Union plays a unifying role. At the same time we need to consider the significant differences among the Balkan countries, which make it impossible to draw a common model describing what is happening in the religious sphere. The common characteristics of religious life in the post-socialist Balkans that can be pointed out are the return of religion to the public sphere with its increased symbolic significance, the tight link between religion and identity, and the coexistence of atheistic and religious life strategies in the society.

\section{Literature}

\section{In Cyrillic}

Baeva, V. 2012. Nishkata na zhivota. Mezhdu kolancheto za rozhba i bogorodichniya poias (Sofia: Prof. Marin Drinov Academic Publishing House).

Baeva, V. 2012a. "Mezhdu enoriiskiya zhivot, poklonnichestvoto i turizma: ruskata tsŭrkva "Sv. Nikolaĭ Mirlikiǔski chudotvorets" v Sofiia," Bŭlgarska etnologia 1-2: 19-36.

Bandić, D. 2004. Narodna religija Srba u 1oo pojmova (Beograd: Neolit). 
Benovska-Sŭbkova, M. 2012. "Ot izuchavane na narodnoto khristiianstvo kŭm antropologia na religiyata. Problemŭt za religiyata v sŭvremenniya sviat," in A. Luleva, V. Vaseva, I. Petrova and P. Hristov (eds.), Etnologiyata v Bŭlgaria. Istoriya, metodi, problemi (Sofia: Prof. Marin Drinov Academic Publishing House): 49-54.

Berger, P. 2004. "Desekularizatsiyata na sveta: globalen pregled," in P. Berger (ed.), Desekularizatsiyata na sveta. Vŭzrazhdashtata se religiya i svetovnata politika (trans. Panaĭotov St.; Sofia: Kritika i khumanizŭm; in original: The Desecularization of the World: Resurgent Religion and World Politics, 1999, William B. Eerdmans Publishing Company): 9-33.

Bogomilova, N. 2005. Religiya, pravo i politika na Balkanite $v$ kraya na XX i nachaloto na ХХІ век (Sofia: Iztok-Zapad).

Bokova, I. 1999. “Zavrŭshtane' na religioznoto (Bŭlgarite katolitsi)," Antropologichni izsledvaniya 1: 57-82.

Bokova, I. 200o. "Kolektivna pamet i religiozna identichnost," in I. Bokova (ed.), Lokalni obshtnosti 1 (Sofia: IK “Iar"): 7-16.

Elchinova, M. 1999. "Religiyata: promiana i traditsiya," Bŭlgarskifolklor 4: 4-14.

Georgieva, A. 2012. Folklorni izmereniya na khristianstvoto (Sofia: Prosveta).

Karamihova, M. 2007. "Edna zhena si izbira religiya," in M. Karamihova (ed.), 'Zavrŭshtane' na religioznostta (Sofia: Etnografski institut s muzeı̌): 127-42.

Karamihova, M. (ed.) 2007a. 'Zavrŭshtane' na religioznostta (Sofia: Etnografski institut s muzeı̌).

Kiurkchieva, I. and M. Koseva 2012. "Oblekloto - mezhdu svetskoto i religioznoto: politiki i identichnost," Bŭlgarska etnologiya 1-2: 104-19.

Malinov, Z. 2007. "Manastirŭt Sveta Nedelia (Mirianina tsŭrkva) - novo svetilishte v ră̌ona na Shtip," in M. Karamihova (ed.), 'Zavrŭshtane' na religioznostta (Sofia: Etnografski institut s muzer) $)$ 41-49.

Popov, R. 2012. "Za edno vŭzrodeno religiozno iavlenie: svettsi pokroviteli na gradove," Bŭlgarska etnologiya 1-2: 50-57.

Radisavljević-Ćiparizović, D. and D. Todorović 2011. Hodočasća - između svetog i svetivnog (Niš: Junir).

Slavkova, M. 2007. Tsiganite evangelistiv Bŭlgaria (Sofia: Paradigma).

Todorović, I. 2008. "Rezultati savremenih istraživanja narodne religije Srba - obšti presek," Glasnik Etnografskog Instituta SANU, LVI (1): 53-70.

Troeva, E. 2011. Religiia, pamet, identichnost: bŭlgarite miusiulmani (Sofia: Prof. Marin Drinov Academic Publishing House).

Valchinova, G. 1999. "Znepolski pokhvali". Lokalna religiya i identichnost v Zapadna Bŭlgaria (Sofia: Prof. Marin Drinov Academic Publishing House).

Valchinova, G. 2006. Balkanski iasnovidki i prorochitsi ot XX vek (Sofia: Bŭlgarski bestselŭr). 
Valchinova, G. 2007. "Vanga' kato legitimirashta strategia: kŭm vŭprosa za t.nar. postkomunistichesko religiozno vŭzrazhdane," in M. Karamihova (ed.), 'Zavrŭstane' na religioznostta (Sofia: Etnografski institut s muzeǔ): 31-40.

Valchinova, G. 2012. "Vŭzrazhdane ili kontinuitet? Postsotzialisticheskata religioznost prez pogleda na neŭnite aktyori," Balkani 1: 62-74.

\section{In the Latin alphabet}

Abazović, D. 2007. "Bosnian Muslims and Country in Transition," in D. Đorđević, D. Todorović and L. Mitrović (eds.), Islam at the Balkans in the Past, Today and in the Future (Niš: Yugoslav Society for the Scientific Study of Religion): 51-55.

Albera, D. and M. Couroucli (eds.) 2012. Sharing Sacred Spaces in the Mediterranean. Christians, Muslims, and Jews at Shrines and Sanctuaries (Bloomington: Indiana University Press).

Altanov, V. 2012. "Religious Revitalization among Bulgarians during and after the Communist time," in J. Filo (ed.) Christian World Community and the Cold War (Bratislava: Evangelical Theological Faculty of the Comenius University of Bratislava): 90-105.

Baeva, V. and G. Valtchinova 2009. "A Women's Religious Organization in Southern Bulgaria: From Miracle Stories to History," History and Anthropology 3: 317-38.

Bakrać, V. 2012. "Religious and folk customs in the north-west part of Montenegro", in D. Đorđević, D. Gavrilović and D. Todorović (eds.) Religion, Religious and Folk Customs on the Border (Niš:Yugoslav Society for the Scientific Study of Religion): 129-39.

Bandić, D. 1997. Carstvo zemaljsko i carstvo nebesko (Beograd: Xx vek).

Barna, G. 2012. "Mechanism of Tradition in Contemporary Religious Practices," Traditiones, 2: 65-76.

Beckford, J. 2003. Social Theory \& Religion (Cambridge: Cambridge University Press).

Beckford, J. and N.J. Demerath (eds.) 2007. The SAGE Handbook of the Sociology of Religion III (London: SAGE Publications).

Beloiu, V.-L. 2015. Miracolul in viata omului modern. O monografie sociologica a pelerinajului. Christiana.

Benovska-Sabkova, M. and V. Altanov 2009. "Evangelical Conversion among the Roma in Bulgaria," Transitions, vol. 48, 2: 133-56.

Berger, P., G. Davie and E. Fokas 2008. Religious America, Secular Europe? A Theme and Variations (Burlington: Ashgate Publishing).

Blagojević, M. 2009. "Empirical (Re)Evaluation of Revitalization of Orthodox Christianity," in D. Gavrilović (ed.) Revitalization of Religion - Theoretical and Comparative Approaches (Niš: Yugoslav Society for the Scientific Study of Religion): 65-70.

Bogomilova, N. 1998. "Religion und sozialer Wandel in Bulgarien," in D. Pollack, I. Borowik and W. Jagodzinski (Hrsg.) Religiöser Wandel in den postkommunistischen Ländern Ost- und Mitteleuropas (Würzburg: Ergon Verlag): 347-69. 
Borowik, I. 2006. "Orthodoxy Confronting the Collapse of Communism in Post-Soviet Countries," Social Compass 2: 267-78.

Borowik, I. 2007. "The Religious Landscape of Central and Eastern Europe after Communism," in J.A. Beckford and N.J. Demerath (eds.), The SAGE Handbook of the Sociology of Religion III (London: SAGE Publications): 654-70.

Božović, R. 2010. "Monastery Ostrog - above the ecumenism," in D. RadisavljevicĆiparizović (ed.), Pilgrimage, Cult Places and Religious Tourism (Niš: Yugoslav Society for the Scientific Study of Religion): 151-54.

Branković, T. and D. Đorđević (eds.). 2006. Protestantism on the Balkans in the Past, Today and the Future (Niš: Yugoslav Society for the Scientific Study of Religion).

Buchenau, K. 2006. Kämpfende Kirchen. Jugoslawiens religiöse Hypothek (Frankfurt am Main: Peter Lang).

Buchenau, K. 2012. "Religion und Nation in Serbien, Bulgarien und Rumänien. Drei verschiedene Wege in Südosteuropa," in A. Ivanišević (Hg.) Re-Sakralisierung des öffentlichen Raums in Südosteuropa nach der Wende 1989? (Frankfurt am Main: Peter Lang): 61-83.

Casanova, J. 1994. Public Religions in the Modern World (Chicago: The Chicago University Press).

Cvitković, I. 2009. "Has the "return" of religions occurred or "return" to the religion?," in D. Gavrilović (ed.) Revitalization of Religion - Theoretical and Comparative Approaches (Niš: Yugoslav Society for the Scientific Study of Religion): 15-23.

Cvitković, I. 2012. "The religious identity at "the border" - an encounter with the other," in D. Đorđević, D. Gavrilović and D. Todorović (eds.) Religion, Religious and Folk Customs on the Border (Niš: Yugoslav Society for the Scientific Study of Religion): 19-23.

Ćiparizović, D. 2015. "Pilgrimage in the $21^{\text {st }}$ century: case studies three sanctuaries in Serbia," Religija i Tolerancija, 24: 331-48.

Čolović, I. 2000. "The Renewal of the Past: Time and Space in Contemporary Political Mythology," Other Voices, v. 2, № 1 (February 200o) [http://www.othervoices.org/2.1/ colovic/past.php].

Čolović. 2011. The Balkans: The Terror of Culture. Essays in Political Anthropology (Baden-Baden: Nomos).

Črnič, A., M. Komel, M. Smrke, K. Šabec, and T. Vovk 2013. "Religious Pluralisation in Slovenia," Teorija in praksa No 50, 1: 205-232.

Davie, G. 2000. Religion in Modern Europe: A Memory Mutates (Oxford: Oxford University Press).

Davie, G. 2002. Europe: The Exceptional Case: Parameters of Faith in the Modern World (London: Darton, Longman and Todd).

Detrez, R. 2015. "Religion in the Yugoslav Successor States at the Beginning of the Twenty-First Century," in B. Radeljić, M. Topić (eds.) Religion in the Post-Yugoslav Context (London: Lexington Books): 17-38. 
Djordjević, D. 2009. "Religiousness of Serbs at the beginning of the 21st century, what is it about?," in D. Gavrilović (ed.) Revitalization of Religion - Theoretical and Comparative Approaches (Niš: Yugoslav Society for the Scientific Study of Religion): 57-64.

Đorđević, D. 2008. "On Religion and Sociology of Religion in the Socialist Yugoslavia and Former Yugoslav Republic," in D. Đorđević (ed.) The Sociology of Religion in the Former Yugoslav Republics (Niš: Yugoslav Society for the Scientific Study of Religion): $5^{-20 .}$

Dorondel, St. 2002. "Orthodoxy, Nationalism, and Local Identities: A Romanian case Study," Ethnologia Balkanica 6: 117-44.

Duijzings, G. 2000. Religion and the Politics of Identity in Kosovo (New York: Columbia University Press).

Dungaciu, D. 2006. "Modernity, Religion and Secularization in the Orthodox Area. The Romanian case," in M. Franzmann, Ch. Gärtner and N. Köck (eds.) Religiösität in der säkularisierten Welt. Theoretische und empirische Beiträge zur Säkularisierungsdebatte in der Religionssoziologie (Wiesbaden: Springer): 241-259.

Dzankic, J. 2016. "Religion and Identity in Montenegro," in I. Murzaku (ed.) Monasticism in Eastern Europe and the Former Soviet Republics (London and New York: Routledge): 110-129.

Elbasani, A. and O. Roy (eds.) 2015. The Revival of Islam in the Balkans. From Identity to Religiosity (London: Palgrave Macmillan).

Endresen, C. 2015. "Faith, Fatherland or Both? Accommodationist and Neo-Fundamentalist Islamic Discourses in Albania," in A. Elbasani and O. Roy (eds.) The Revival of Islam in the Balkans. From Identity to Religiosity (London: Palgrave Macmillan): 222-241.

Flora, G., G. Szilagyi and V. Roudometof 2005. "Religion and national identity in postcommunist Romania," Journal of Southern Europe and the Balkans, 7 (1): 35-55.

Fosztó, L. 2009. Ritual Revitalization after Socialism: Community, Personhood, and Conversion among Roma in a Transylvania Village (Berlin: Lit Verlag).

Gavrilović, D. (ed.) 2009. Revitalization of Religion - Theoretical and Comparative Approaches (Niš: Yugoslav Society for the Scientific Study of Religion): 15-23.

Ghodsee, K. 2009. Muslim Lives in Eastern Europe: Gender, Ethnicity, and the Transformation of Islam in Postsocialist Bulgaria (Princeton: Princeton University Press).

Gog, S. 20o6. "The construction of the religious space in post-socialist Romania," Journal for the Study of Religions and Ideologies, 5 (15): 37-53.

Grigore, M. 2015. "Tamara's Illness. Pilgrims, Fate, and Lived Religion in Post-Communist Romania," Religion and Society in Central and Eastern Europe, 8 (1): 39-51.

Hann, C. and the "Civil Religion" Group (eds.) 2006. The Postsocialist Religious Question. Faith and Power in Central Asia and East-Central Europe (Berlin: Lit Verlag).

Henkel, R. 2011. "Identity, Ethnicity and Religion in the Western Balkans," in C. Brace, A. Bailey, S. Carter, D. Harvey and N. Thomas (eds.) Emerging Geographies of Belief (Cambridge Scholars Publishing): 91-111. 
Hristov, P. 2012. "Religious markers of identity in the context of labour mobility in Western Macedonia, Bulgaria and Eastern Serbia," in D. Đorđević, D. Gavrilović and D. Todorović (eds.), Religion, Religious and Folk Customs on the Border (Niš: Yugoslav Society for the Scientific Study of Religion): 287-94.

Hristov, P. and M. Hristova 2014. "Sacred places and cultural memory on the tripleshared border-pilgrimage in the Osogovo monastery," Etnolog, 15, 45-61.

Iveković, I. 2002. "Nationalism and the Political Use and Abuse of Religion: The Politicization of Orthodoxy, Catholicism and Islam in Yugoslav Successor States," Social compass 4: 523-36.

Jakelić, S. 2010. Collectivistic Religions. Religion, Choice, and Identity in Late Modernity (Burlington: Ashgate Publishing).

Jerolomov, D. and S. Zrinščak 20o6. "Religion Within and Beyond Borders: The Case of Croatia," Social Compass 2: 279-9o.

Jovanović, Z. and J. Petrović 2012. "On Certain Christian and Christianized cults in Southeastern Serbia," in D. Đorđević, D. Gavrilović and D. Todorović (eds.) Religion, Religious and Folk Customs on the Border (Niš: Yugoslav Society for the Scientific Study of Religion): 141-54.

Kanev, P. 2002. "Religion in Bulgaria after 1989: historical and sociocultural aspects," South-East Europe Review 1: 75-96.

Karamihova, M. and G. Valtchinova 2009. "Talking War, "Seeing” Peace: Approaching the Pilgrimage of Krastova Gora (Bulgaria)," History and Anthropology 3: 339-62.

Kolczyńska, M. 2012. "Religion in public space in Kosovo after 1989," in A. Ivanišević (Hg.), Re-Sakralisierung des öffentlichen Raums in Südosteuropa nach der Wende 1989? (Frankfurt am Main: Peter Lang): 167-78.

Krasteva, A. 2015. "Religion, Politics, and Nationalism in Postcommunist Bulgaria: Elastic (Post)Secularism," Nationalism and Ethnic Politics, 21 (4): 422-445.

Krstic, D. 2010. "A contribution to the typology of cult places of the Balkans," in D. Radisavljević-Ćiparizović (ed.) Pilgrimage, Cult Places and Religious Tourism (Niš: Yugoslav Society for the Scientific Study of Religion): 129-40.

Kuburić, Z. and M. Kuburić-Borović 2009. "Revitalization of religion in the Balkans," in D. Gavrilović (ed.), Revitalization of Religion - Theoretical and Comparative Approaches (Niš: Yugoslav Society for the Scientific Study of Religion): $45^{-56}$.

Luckmann, T. 2003. "Transformations of Religion and Morality in Modern Europe," Social Compass 3: 275-85.

Maner, H.-Ch. 2012. "Die Rolle der Rumänisch-Orthodoxen Kirche nach der Wende 1989/9o," in A. Ivanišević (Hg.) Re-Sakralisierung des öffentlichen Raums in Südosteuropa nach der Wende 1989? (Frankfurt am Main: Peter Lang): 85-98.

Markle, G. and F. McCrea 1994. "Medjugorje and the Crisis in Yugoslavia," in W. Swatos (ed.) Politics and Religion in Central and Eastern Europe. Traditions and Transitions (London: Praeger Publishers): 197-208. 
Merdjanova, I. 2013. Rediscovering the Umma. Muslims in the Balkans between Nationalism and Transnationalism (Oxford: Oxford University Press).

Ognjenović, G. and J. Jozelić (eds.) 2014. Politicization of Religion, the Power of State, Nation, and Faith: The Case of Former Yugoslavia and its Successor States (Palgrave Macmillan).

Pătru, A. 2011. "Religion in Rumänien heute," in B. Groena and S. Löser (Hg.), Der Balkan. Religion, Gesellschaft und Kultur (Innsbruck: Tyrolia Verlagsanstalt): 59-75.

Pickel, G. "Revitalization of Religiosity as Normalization? Romania in European Comparative Perspective," Studia Universitatis Babes-Bolyai-Sociologia, 2: 9-36.

Pollack, D. 2003. Säkularisierung - ein moderner Mythos? (Tübingen: Gulde Druck).

Potrata, B. 2004. "New Age, Socialism and Other Millenarianisms: Affirming and Struggling with (Post)socialism," Religion, State \& Society 4: 365-79.

Radeljić, B. and M. Topić (eds.) 2015. Religion in the Post-Yugoslav Context (London: Lexington Books).

Radisavljević-Ćiparizović, D. 2010. "Mixed pilgrimages in Serbia: Question of communitas and pilgrims' identity," in D. Radisavljević-Ćiparizović (ed.), Pilgrimage, Cult Places and Religious Tourism (Niš: Yugoslav Society for the Scientific Study of Religion): $155^{-65}$.

Radisavljević-Ćiparizović, D. 2011. "Pilgrimage in empirical perspective: pilgrims' attitudes towards church and folk religiosity and superstition in Serbia," in M. Blagoević and D. Todorović (eds.), Orthodoxy from an Empirical Perspective (Beograd - Niš: Yugoslav Society for the Scientific Study of Religion): 127-37.

Radulovic, L. 2010. “Gender aspects of pilgrimage in Serbia from the 1990's until present," in D. Radisavljević-Ćiparizović (ed.) Pilgrimage, cult places and religious tourism (Niš: Yugoslav Society for the Scientific Study of Religion): 141-50.

Ramet, S. (ed.) 2014. Religion and Politics in Post-Socialist Central and Southeastern Europe. Challenges since 1989 (London: Palgrave Macmillan).

De Rapper, G. 2010. "Religion on the border: Sanctuaries and festivals in post-communist Albania," in G. Valtchinova (ed.) Religion and Boundaries. Studies from the Balkans, Eastern Europe and Turkey (Istanbul: Isis Press): 247-65.

Şerban, S. 2010. "Pilgrimage and Nationhood in a Transylvanian village," in G. Valtchinova (ed.) Religion and Boundaries. Studies from the Balkans, Eastern Europe and Turkey (Istanbul: Isis Press): 167-85.

Stan, L. and L. Turcescu 2007. Religion and Politics in Post-Communist Romania (Oxford: Oxford University Press).

Todorovic, D. (ed.) 2004. Evangelization, Conversion, Proselytism (Niš: Yugoslav Society for the Scientific Study of Religion).

Tomka, M. 2002. "Tendences de la religiosité et de l'orientation vers les Eglises en Europe de l'Est," Social Compass 4: 537-52. 
Tomka, M. 2011. Expanding Religion. Religious Revival in Post-Communist Central and Eastern Europe (Berlin, New York: Hubert\&Co).

Toncheva, S. 2015. Out of the New Spirituality of the Twentieth Century. The Dawn of Anthroposophy, the White Brotherhood and the Unified Teaching (Berlin: Frank \& Timme).

Troeva, E. 2015. "Signs of religious affiliation and their usage," Ethnologia bulgarica, vol. 4: 45-58.

Troeva, E. 2016. "Transformationen im religiösen Leben der bulgarischen Muslime in der postsozialistischen Periode," Jahrbuch für Europäische Ethnologie, 173-186.

Troeva, E. 2016a. "New Age Pilgrimages in Bulgaria," Bŭlgarski folklor, special edition, $54-71$.

Valtchinova, G. 1999. "Le pèlerinage du "Mont de la Croix" et l'apprentissage religieux en Bulgarie post-communiste," Cahiers de litterature orale 45: 87-110.

Valtchinova, G. 2001. "Communisme "orthodoxe" et changement religieux: leçons du terrain bulgare," Ethnologia Balkanica 5: 59-77.

Valtchinova, G. 2005. "Krastova gora et les réseaux de dévotion populaire orthodoxe dans les Rhodopes," Études Balkaniques 2: 45-67.

Valtchinova, G. 2007. From Postsocialist Religious Revival to a Socialist Seer and Vice Versa: the remaking of religion in postsocialist Bulgaria Working Papers № 98 (Halle / Saale: Max Planck Institute for Social Anthropology).

Valtchinova, G. 2008. “Jérusalem des Rhodopes" vs. "La Mecque des Rhodopes": deux lieux de pèlerinage entre la Bulgarie, la Grèce et la Turquie," Chronos. Revue d'Histoire de l'Université de Balamand 18: 55-86.

Valtchinova, G. 2009. "Medjugorje et Krăstova Gora dans la longue durée: partage et construction de frontières dans deux pèlerinages chrétiens des Balkans," Études Balkaniques 1: 168-95.

Voicu, M. and A. Constantin 2012. "Religious Revival in Romania: Between Cohort Replacement and Contextual Changes," in G. Pickel and K. Sammet (eds.) Transformations in Religiosity: Religion and Religiosity in Eastern Europe 1989 - 2010 (Wiesbaden: Springer): 155-74.

Vrcan, S. 1986. Od krize religije k religiji krize (Zagreb: Školska knjiga).

Zielińska, K. 2013. "Concepts of religion in debates on secularization," Approaching Religion 1: $25-35$.

Zrinčšak, S. 2006. "Anonymous Believers as Sociological Challenge: Religions and Religious Changes in Post-Yugoslav States," in I. Borowik (ed.) Religions Churches and Religiosity in Post-Communist Europe (Krakow: Nomos): 68-80.

Zrinčšak, S. 2008. "Sociology of Religion in Croatia 1991-2007," in D. Đorđević (ed.) The Sociology of Religion in the Former Yugoslav Republics (Niš: Yugoslav Society for the Scientific Study of Religion): 26-42. 